\title{
Evaluation of the Influence of Frequency of Milk Collection and Milking Dayshift on the Microbiological Quality of Raw Milk
}

\author{
Lucía Reguillo, ${ }^{1,2}$ Manuela Hernández, ${ }^{2}$ Elisabeth Barrientos, ${ }^{2}$ \\ Fernando Perez-Rodriguez $\mathbb{D}^{\mathbb{D}},{ }^{1}$ and Antonio Valero $\mathbb{D i}^{1}$ \\ ${ }^{1}$ Department of Food Science and Technology, Universidad de Córdoba, Córdoba, Spain \\ ${ }^{2}$ CICAP Agrifood Research Center, Pozoblanco, Córdoba, Spain
}

Correspondence should be addressed to Fernando Perez-Rodriguez; b42perof@uco.es

Received 2 December 2017; Accepted 2 April 2018; Published 21 May 2018

Academic Editor: Efstathios Giaouris

Copyright (C) 2018 Lucía Reguillo et al. This is an open access article distributed under the Creative Commons Attribution License, which permits unrestricted use, distribution, and reproduction in any medium, provided the original work is properly cited.

\begin{abstract}
The aim of this study was to analyze the influence of milk collection frequency ( $24 \mathrm{~h}$ versus $48 \mathrm{~h}$ ) and milking dayshift (morning and evening) on total mesophilic aerobic bacteria (MAB) and psychrotrophic bacteria (PSY) counts in raw milk samples. MAB counts were determined by flow cytometry (BactoScan) and PSY counts by the plate counting agar method. An univariate statistical analysis was performed to find out significant differences among the studied factors. Results obtained showed that collecting milk every $24 \mathrm{~h}$ was effective in reducing MAB and PSY counts by 32 and $18 \%$, respectively, compared to $48 \mathrm{~h}$ milk collection. This positive impact allowed reducing up to $4^{\circ} \mathrm{C}$ the temperature of the heat treatment in the dairy industry, thus involving energy savings of $22 \%$. Milking during the mornings showed a significant reduction of MAB counts in comparison to milking performed during the evenings $(P<0.05)$. These results are highly useful for the improvement of milk quality through the optimization of collection and milking systems set at primary production.
\end{abstract}

\section{Introduction}

The widespread use of refrigerating raw milk from milking on the farm to its delivery to dairy industries mitigates the risk of product deterioration associated with the growth of thermophilic and mesophilic microorganisms and proliferation of pathogenic microorganisms [1]. Raw milk contains saprophytic bacteria with glycolytic, proteolytic, and lipolytic activities. Their presence and multiplication can be conditioned by storing raw milk below $7^{\circ} \mathrm{C}$, favoring the selection of psychrotrophic species such as Pseudomonas spp., Alcaligenes spp., Bacillus cereus, Lactobacillus, Micrococcus, and Streptococcus and species of Enterobacteriaceae family. Thermophilic and mesophilic microorganisms may be ubiquitous in nature and can be found on operators' hands or in udders, milking parlours, milk containers, and so on [1]. Pseudomonas spp., E. coli, heat-resistant streptococci, and Bacillus spores have been isolated from biofilms that might form in milking equipment [2]. Cleaning and disinfecting milking equipment, proper preparation of udders, and correct hygienic practices are essential to reduce bacterial counts [3]. Although there is no scientific evidence confirming that milking dayshift influences microorganism counts, factors related to the stage of lactation, diet composition, and energy status have been described to favor lipolysis due to their influence on milk lipases [4].

One of the routine analyses of dairy industries to check the hygienic-sanitary quality of milk is monitoring the total bacterial counts at $30^{\circ} \mathrm{C}$. The current $\mathrm{EU}$ regulation requires MAB counts to be below 100,000 CFU/mL (Regulation EC 853/2004), while EU standards by food business operators normally set a more stringent limit for the production of highquality milk (30,000 CFU/mL) [1]. In terms of psychrotrophic bacteria (PSY) counts, different limits associated with highquality milk have already been established in EU standards such as $5,000 \mathrm{CFU} / \mathrm{mL}$ [1]. This is because psychrotrophic bacteria are currently considered as an additional quality indicator, and in countries like the Czech Republic, a limit of 50,000 CFU/mL has already been established [5]. Enzymatic degradation produced by this microbial group can contribute to casein and lipid degradation, causing product spoilage 


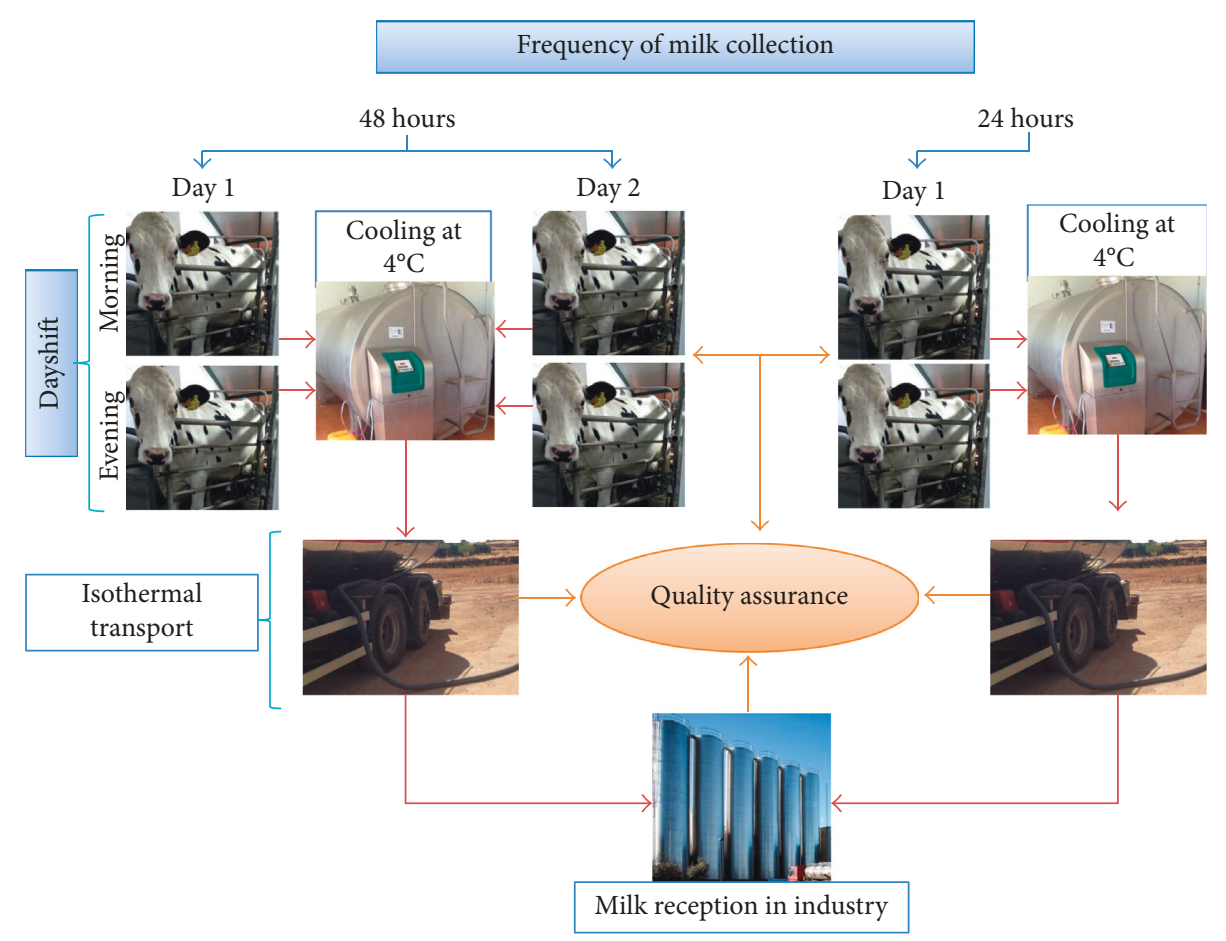

FIGURE 1: Steps in the milk primary production chain from the farm to the dairy industry considering two frequencies of milk collection at the farm (i.e., 24 and $48 \mathrm{~h}$ ).

$[6,7]$. In this line, some studies have used PSY counts to predict milk stability after heat treatment and packaging [7]. Moreover, since PSY counts are also indicators of poor hygienic conditions $[1,3]$, it would be worthy to further investigate the relationship between MAB and PSY counts in raw milk samples and how they can affect final milk quality.

Storing time and temperature of raw milk from collection until reception in dairy industries is definitely one of the key factors helping to preserve milk quality. Milk must be transported in conditions that guarantee the maintenance of the cold chain without exceeding $10^{\circ} \mathrm{C}$. According to $\mathrm{Eu}-$ ropean legislation, milk must be cooled down to a maximum of $6^{\circ} \mathrm{C}$ in the industrial level unless it is treated immediately (Regulation EC no. 853/2004). Heat treatment of milk aims to extend the shelf-life, reducing the microbial load [8].

Ultra-heat treatment (UHT) guarantees the safety and stability of milk for months, maintaining the organoleptic qualities of the milk unaltered (Regulation EC no. 853/2004). This treatment applies continuous heat at high temperature, not less than $135^{\circ} \mathrm{C}$, for a short period of time (between 4 and 15 seconds). During the application of such treatment in the dairy industry, energy is expended as a result of the temperature and time applied. This expense can be quantified by measuring the tons of steam generated during treatment.

Reducing time elapsed from milking to the heat treatment of milk might minimize spoilage due to microbial growth and enzymatic activity. To this end, the frequency of milk collection by trucks on farms should be increased from collection for every 48 hours to daily collection. In Spain, dairy industries must ensure that milk is stored under isothermal conditions in both tanker trucks during transport and receiving silos in the industry, requiring temperatures in the tank at the farm level to be less than $8^{\circ} \mathrm{C}$ when milk collection is performed on a daily basis or below $6^{\circ} \mathrm{C}$ when milk collection is less frequently carried out (Spanish Royal Decree no. 1600/2011).

This study was aimed at examining the influence of milking dayshift and the time elapsed between milking and its delivery to the industry (frequency of milk collection) on the MAB and PSY counts analyzed in raw milk. Besides, the impact of daily collection on energy expenditure in the industry was quantified.

\section{Materials and Methods}

2.1. Sampling. A total of 778 milk samples taken from 29 tankers from 232 suppliers were analyzed. Of these 778 samples, 391 corresponded to milk collected after 48 hours during February 2016 and 387 to milk collected daily (24 h) during March 2016. Milk was collected from the cattle farms by tankers. Hoses connected to the tanks poured the refrigerated milk into different compartments. The milk stored within the tank trucks was kept at isothermal conditions.

The tank trucks collected milk from different livestock farms and then made final delivery to the industry where analyses were carried out prior to milk unloading in silos (Figure 1).

Farms, in this study, were located in the northern Andalusia region (Spain) within a radius of less than 80 kilometres from dairy industry facilities. The livestock corresponded to high-yield Friesian cows (35 liters of milk per day). The farms participating in the study followed the production guidelines set out in the Cow Raw Milk Production Manual of the Ministry of Agriculture and Fisheries, 
Food and Environment. The milk was produced by animals that complied with the health requirements established by European legislation (Regulation EC no. 853/2004), which requires levels of $\leq 100,000 \mathrm{CFU} / \mathrm{mL}$ for bacterial counts at $30^{\circ} \mathrm{C}$ (moving the geometric mean observed over a period of two months, with a minimum of two samples per month).

Milk samples were collected when the tanks were delivered to the industry by each tank truck under aseptic conditions using alcohol-disinfected tongs to hold sterile containers, which were subsequently capped, identified, and stored at $4^{\circ} \mathrm{C}$ until their analysis in the laboratory. For sample collection, two $40 \mathrm{~mL}$ samples were taken from each tank at the time of delivery to the industry; the milk was previously mixed to ensure its correct homogenization (Spanish Royal Decree no. 1728/2007).

2.2. Studied Factors Associated with Milk Collection. The first factor studied was milking dayshift, which corresponded to two different periods: mornings or dayshift 1 (6:00-9:00 h) and evenings or dayshift 2 (17:00-20:00 h). From three to four hours after each milking, milk was collected and transported under conditions described in Section 2.1.

The second factor analyzed was the frequency of milk collection, which corresponded to two periods: (i) daily collection (24 h) during March 2016 and (ii) daily collection for every $48 \mathrm{~h}$ during February 2016 in the livestock farms.

2.3. Microbiological Analyses. $\mathrm{MAB}$ were determined in the laboratory using BactoScan ${ }^{\mathrm{TM}} \mathrm{FC}+$ (Foss, Denmark). To stabilize milk samples microbiologically, a volume of $133 \mu \mathrm{l}$ azidiol (sodium azide/chloramphenicol) was added to each $40 \mathrm{~mL}$ sample [9]. The results expressed in pulses of BactoScan $/ \mathrm{mL}$ were transformed into $\mathrm{CFU} / \mathrm{mL}$, according to the following equation:

$$
y=0.884 x+0.243
$$

where $y=\log \mathrm{CFU} / \mathrm{mL}$ and $x=\log$ BactoScan $/ \mathrm{mL}$ pulses, considering a detection limit of 10,000 CFU/mL (Spanish Royal Decree no. 1600/2011).

For the determination of PSY counts, tenfold dilutions from the milk samples were performed and $0.1 \mathrm{~mL}$ was plated onto plate count agar (Oxoid, Spain) using the International Dairy Federation procedure (1985). The control and inoculated plates were left to air-dry at room temperature before being incubated at $7^{\circ} \mathrm{C}$ for 10 days. PSY counts were expressed in $\mathrm{CFU} / \mathrm{mL}$, while the limit of quantification was $100 \mathrm{CFU} / \mathrm{mL}$.

Raw milk samples at both dayshifts and for both types of collection were analyzed in duplicate in order to capture the variability in microbial counts.

2.4. Assessing Energy Consumption in Heat Treatment. In those milk samples having reduced MAB and PSY counts, the heat treatment temperature could be lowered to $4^{\circ} \mathrm{C}$, maintaining the same milk organoleptic quality. This temperature was selected within the typical working range allowed for UHT milk. The amount of steam generated in two 8-month periods (Tm) (April 2015-December 2015 and April 2016-December 2016) was compared to that of the typical heat treatment before April 2016 and treatment applied using a reduction of $4^{\circ} \mathrm{C}$ from this date onwards. To measure the steam generated during the heat treatment of milk, quantometers were placed in the Vortex-type thermizers (Emerson, USA). Quantometers were used with a built-in temperature probe capable of indicating steam temperature and quantifying supplied energy. The percentage of energy savings was calculated according to the steam saturation table obtained in accordance with the ISO 9001 standard, using the enthalpy of steam as a reference value and the key performance index (KPI) relating milk production per month and the associated steam to energy cost.

2.5. Statistical Analysis. The data obtained from microbial counts were processed in MS Excel (Microsoft, Redmond, USA). The average, maximum, and minimum values of $\mathrm{MAB}$ and PSY results were calculated, in CFU/mL, for the milking dayshifts and frequencies of collection considered in this study.

Microbiological milk samples were also classified according to quality criteria applied by the dairy companies under study. For MAB count, the criteria consisted of $\leq 50,000 \mathrm{CFU} / \mathrm{mL}$ as a quality premium payment, $>50,000$ to $<100,000 \mathrm{CFU} / \mathrm{mL}$ for minimum payment, and $\geq 100,000$ $\mathrm{CFU} / \mathrm{mL}$ for milk not suitable for processing at the industrial level in accordance with the requirements established in Regulation no. 853/2004. For PSY levels, milk samples were classified into two quality ranges, that is, $\leq 10,000$ and $>10,000 \mathrm{CFU} / \mathrm{mL}$. These ranges are associated with the absence or presence of enzymatic alterations (e.g., lipolysis) in the finished product $[3,7]$.

For statistical analysis, SPSS version 15.0 (Chicago, Illinois, USA) was used. A variance homogeneity test (Levene statistic) was performed, as well as a series of parametric tests (ANOVA) and nonparametric tests (Kruskal-Wallis test) analyzing the dayshift and type of collection as independent variables and the microbial counts as dependent variables. Significant differences were considered with a confidence level of $95 \%(P<0.05)$.

\section{Results and Discussion}

3.1. Analysis of the Effect of the Milk Collection Frequency (24 and $48 \mathrm{~h}$ ) on Microbial Counts. According to the results obtained, in the samples collected after $24 \mathrm{~h}(n=387)$, the count ranges were $1.0 \times 10^{4}-1.8 \times 10^{5}$ and $1.0 \times 10^{2}-7.3 \times$ $10^{4} \mathrm{CFU} / \mathrm{mL}$ for MAB and PSY, respectively. For the samples collected after 48 hours $(n=391)$, values ranged in the intervals $1.0 \times 10^{4}-9.9 \times 10^{5} \mathrm{CFU} / \mathrm{mL}$ and $1 \times 10^{2}-2.7 \times$ $10^{5} \mathrm{CFU} / \mathrm{mL}$ for MAB and PSY, respectively.

The largest mean value was obtained for MAB in milk collected every $48 \mathrm{~h}$, with a value of $4.4 \times 10^{4} \mathrm{CFU} / \mathrm{mL}$. This value was 10 times higher than that obtained for PSY at 24 and $48 \mathrm{~h}\left(4.4 \times 10^{3}\right.$ and $5.4 \times 10^{3} \mathrm{CFU} / \mathrm{mL}$, resp.). The coefficient of variance denoted a high variation in counts, which was remarkably higher for two-day collection (Table 1). 
TABle 1: Mesophilic aerobic bacteria (MAB, CFU/mL) and psychrotrophic bacteria (PSY, CFU/mL) counts obtained according to the frequency of milk collection (24 and $48 \mathrm{~h})$.

\begin{tabular}{lcccccccc}
\hline Microorganisms & $\begin{array}{c}\text { Collection } \\
\text { time }(\mathrm{h})\end{array}$ & Mean & Min. & Max. & $\begin{array}{c}\text { Standard } \\
\text { deviation }\end{array}$ & $\begin{array}{c}\text { 5th } \\
\text { percentile }\end{array}$ & $\begin{array}{c}\text { 95th } \\
\text { percentile }\end{array}$ & $\begin{array}{c}\text { Coefficient of } \\
\text { variation }(\%)\end{array}$ \\
\hline MAB & 24 & 29,599 & 10,000 & 175,000 & 27,185 & 10,000 & 75,000 & 92 \\
MAB & 48 & 44,016 & 10,000 & 993,000 & 78,730 & 11,000 & 91,000 & 179 \\
PSY & 24 & 4,432 & 100 & 73,000 & 7,011 & 100 & 16,000 \\
PSY & 48 & 5,459 & 100 & 270,400 & 20,138 & 100 & 17,080 & 369 \\
\hline
\end{tabular}

The results of the statistical analysis indicated that there was not variance homogeneity in the observed data $(P<0.05)$. For this reason, a nonparametric Kruskal-Wallis test was applied to study the differences in microbial counts associated with the frequency of milk collection and milking dayshift. When examining the mean counts, milk collected every $48 \mathrm{~h}$ showed an increase in counts of $32 \%$ and $18 \%$ with respect to milk collected every $24 \mathrm{~h}$ for MAB and PSY, respectively.

The Kruskal-Wallis test revealed significant differences $(P<0.05)$ in the MAB counts obtained for different milking dayshifts, while no significant differences were observed in PSY counts $(P \geq 0.05)$. The reduction observed for MAB counts could have been influenced by the shorter time from milk collection till reception in the industry, which led to lower microbial growth. Likewise, higher maximum population densities were reached when milk was collected every $48 \mathrm{~h}$ rather than daily milk collection. Other studies that investigated the effects of housing and milking technologies on the milk quality showed similar counts for PBC and MAB compared to the obtained count of $24 \mathrm{~h}$ collection for the present study $[3,5]$. The association between the elapsed time and the increase of microbial load has been previously described by other studies $[10,11]$.

The ratio of MAB and PSY can be used to analyze the effectiveness of different measures applied for improving hygienic-sanitary conditions of raw milk and understanding the relationship between both groups of microorganisms. According to European standards for high-quality milk, counts shall not exceed $30,000 \mathrm{CFU} / \mathrm{mL}$ of $\mathrm{MAB}$ and $5,000 \mathrm{CFU} / \mathrm{mL}$ of PSY (ratio 6:1) because higher values and ratios are related to increases in the proportions of proteolytic and lipolytic phenomena [5]. Mean counts observed for 24 hours of collection were very close to those in the EU standards of MAB and PSY (29,599 and 4,432 CFU/mL, resp.); however, the ratio of MAB: PSY for $48 \mathrm{~h}$ collection was approximately $8: 1(44,016: 5,459 \mathrm{CFU} / \mathrm{mL})$.

Another effect of daily milk collection (24h) was the reduction in the number of milkings ( 4 and 2 milkings for 48 and $24 \mathrm{~h}$, resp.). The frequency of milk collection influenced the temperature rise of the milk stored in the tank. For instance, when two milkings are carried out daily and milk is collected every two days ( $48 \mathrm{~h}$ ), milk would be obtained from 4 milkings on two consecutive days, thus implying that the milk obtained from the first milking would increase by up to $3^{\circ} \mathrm{C}$ due to the addition of fresh milk $\left(\sim 38^{\circ} \mathrm{C}\right)$ (the second milking on day 1 and the first and second milkings on day 2). In contrast, if the milk is daily collected, the amount of milk coming from the first milking presents only one temperature rise. Then, milk is cooled until lower temperatures are reached $\left(4^{\circ} \mathrm{C}\right)$. Although the effect of both frequencies of milk collection ( $24 \mathrm{~h}$ and $48 \mathrm{~h}$ ) on changes in chemical properties and sensory quality of milk has not yet been investigated, temperature rises during raw milk storage can lead to a redistribution of milk lipase enzymes by increasing their contact with fat, thus accelerating the hydrolysis of fat globules and the production of oxidation and browning phenomena [12].

This is in line with other studies in which high levels of PSY in raw milk were associated with the presence of thermostable lipases and proteases, causing alterations in both fat and casein proteins after heat treatment [13]. Although time and temperature are relevant factors involved in milk degradation, the proteolytic and lipolytic activity of PSY also depends on the hygienic practices and milking system employed [14]. The reduction in both MAB and PSY counts during daily collection could contribute to the fact that no incidences of proteolysis were recorded in the industry.

The improvement in the microbiological quality of milk associated with storage time has also been described by other authors who reported greater enzymatic degradation of milk (up to $7 \%$ ) in $48 \mathrm{~h}$ when compared with fresh samples [14] and a correlation between milk samples with counts of more than $10,000 \mathrm{CFU} / \mathrm{mL}$ of PSY stored at $7^{\circ} \mathrm{C}$ with milk spoilage [7]. Although scientific literature indicates that time and initial contamination are determinants of PSY proliferation, the results of the statistical analysis described in this study did not show significant differences associated with the reduction of collection time $(24 \mathrm{~h})$ in the decrease of PSY; hence, further research would be necessary to examine the role that certain livestock farms with high levels of PSY may have on milk quality stored for more than 48 hours.

\subsection{Analysis of the Effect of Milking Dayshift on Microbial} Milk Counts. The ranges of counts obtained for milking dayshift 1 (mornings) were $1.0 \times 10^{4}-9.9 \times 10^{5} \mathrm{CFU} / \mathrm{mL}$ and $1.0 \times 10^{2}-2.7 \times 10^{5} \mathrm{CFU} / \mathrm{mL}$ for MAB and PSY, respectively, while for milking dayshift 2 (evenings), microbial counts ranged between $1.0 \times 10^{4}-4.2 \times 10^{5} \mathrm{CFU} / \mathrm{mL}$ and $1.0 \times 10^{2}-$ $7.3 \times 10^{4} \mathrm{CFU} / \mathrm{mL}$, respectively.

Both MAB and PSY counts were statistically lower for milking in the morning according to the Kruskal-Wallis statistical analysis $(P<0.05)$.

By comparing the above shown results in Table 2 with the European standards for high-quality milk (ratio of MAB and PSY, 6:1), the mean ratio of morning and evening 
TABLE 2: Mesophilic aerobic bacteria (MAB, CFU/ml) and psychrotrophic bacteria (PSY, CFU/ml) counts obtained according to the milking dayshift (morning and evening).

\begin{tabular}{lcccccccc}
\hline Microorganisms & $\begin{array}{c}\text { Milking } \\
\text { dayshift }\end{array}$ & Mean & Min. & Max. & $\begin{array}{c}\text { Standard } \\
\text { deviation }\end{array}$ & $\begin{array}{c}\text { 5th } \\
\text { percentile }\end{array}$ & $\begin{array}{c}\text { 95th } \\
\text { percentile }\end{array}$ & $\begin{array}{c}\text { Coefficient of } \\
\text { variation }(\%)\end{array}$ \\
\hline MAB & Morning & 36,928 & 10,000 & 993,000 & 59,361 & 10,000 & 86,000 & 161 \\
MAB & Evening & 38,369 & 10,000 & 420,000 & 60,593 & 12,000 & 87,000 \\
PSY & Morning & 4,970 & 100 & 270,400 & 15,097 & 100 & 16,100 \\
PSY & Evening & 5,230 & 100 & 73,000 & 15,452 & 100 & 16,550 & 304 \\
\hline
\end{tabular}

milking counts was slightly higher than that of the EU standards $(7: 1)$.

The coefficient of variance informed a high variation in counts, which was again remarkably higher for PSY.

To the best of our knowledge, there is a lack of information in literature explaining these microbial differences in milk quality as a function of the milking dayshift. Nonetheless, chemical parameters of milk, especially lactose, ash, nonfat solids, and total solids, play an essential role as nutrients for bacteria [15]. Cow physiology, diet composition, negative energy balance, or low concentrations of insulin can influence milk composition and therefore bacterial growth. Higher free fatty acid contents can result from spontaneous and induced lipolysis associated with evening milking. [4]. Furthermore, biosanitary conditions in the livestock farms, good hygienic practices, and collection trucks and equipment and facilities management may also influence microbial counts in milk associated with milking dayshift [16]. Unlike agri-food industries, farms are not required to conduct an HACCP (Hazard Analysis and Critical Control Points), but they need to adhere to good manufacturing and hygienic practices. Moreover, in addition to the European "Hygiene Package" regulations, Spain published a Guide to Correct Practices for Dairy Cattle Breeding developed by the Interprofessional Dairy Organization (INLAC) in 2005, which outlines requirements and good practices grouped by areas within the first phase of milk production [17].

3.3. Classification of Results according to Quality Ranges. The results for MAB and PSY counts classified by the quality ranges established as a function of $24 \mathrm{~h}$ and $48 \mathrm{~h}$ collection and milking dayshift are presented in Tables 3 and 4, respectively.

When the results were classified by range, samples with counts of MAB above 50,000 CFU/mL collected every $48 \mathrm{~h}$ were $12 \%$ higher than samples collected every $24 \mathrm{~h}$ ( 97 and 50 , resp. $(P<0.05)$. Likewise, the number of samples collected every $24 \mathrm{~h}$ with $\mathrm{MAB}$ counts below $50,000 \mathrm{CFU} / \mathrm{mL}$ was $12 \%$ higher than that of samples collected every $48 \mathrm{~h}$ (337 and 294, resp.). However, PSY counts did not present significant differences between the two types of milk collection.

The classification of the results according to quality ranges, as described in Introduction, showed that daily collection enabled the microbiological quality of the milk to be maintained within the $\mathrm{CFU} / \mathrm{mL}$ levels suitable for the industry $(<100,000 \mathrm{CFU} / \mathrm{mL}$ is the limit for milk collection
TABle 3: Percentage of samples according to the quality standards of the industry and frequency of milk collection ( 24 and $48 \mathrm{~h}$ ) for mesophilic aerobic bacteria (MAB) and psychrotrophic bacteria (PSY).

\begin{tabular}{lccc}
\hline Microorganisms & Range $(\mathrm{CFU} / \mathrm{mL})$ & $24 \mathrm{~h}$ & $48 \mathrm{~h}$ \\
\hline \multirow{2}{*}{ MAB } & $<50,000$ & $337(87 \%)$ & $294(75 \%)$ \\
& $\geq 50,000$ & $50(13 \%)$ & $97(25 \%)$ \\
PSY & $<10,000$ & $340(88 \%)$ & $345(89 \%)$ \\
& $\geq 10,000$ & $47(12 \%)$ & $46(11 \%)$ \\
\hline
\end{tabular}

TABle 4: Percentage of samples according to the quality standards of the industry and milking dayshift (morning and evening) for mesophilic aerobic bacteria (MAB) and psychrotrophic bacteria (PSY).

\begin{tabular}{lccc}
\hline Microorganisms & Range $(\mathrm{CFU} / \mathrm{ml})$ & Morning & Evening \\
\hline \multirow{2}{*}{ MAB } & $<50,000$ & $294(83 \%)$ & $333(80 \%)$ \\
& $\geq 50,000$ & $61(17 \%)$ & $84(20 \%)$ \\
PSY & $<10,000$ & $302(85 \%)$ & $383(92 \%)$ \\
& $\geq 10,000$ & $53(15 \%)$ & $34(8 \%)$ \\
\hline
\end{tabular}

and minimum payment). Note that minimum payment refers to the minimal microbial counts required for milk enabling the payment by the dairy industry.

Regarding milking dayshift (morning and evening), no significant differences were observed in MAB counts $(P \geq 0.05)$. In contrast, when milk was obtained in the evening, the number of samples presenting PSY counts above $10,000 \mathrm{CFU} / \mathrm{mL}$ decreased by $7 \%$ significantly $(P<0.05)$. When ranges of CFU/mL of PSY were below 10,000, the evening milking showed also an increase of $7 \%$ of milk samples compared with morning milking (383 and 302, resp.).

These results were contrary to those derived from the statistical analysis of microbial counts, when ranges were not applied. The reasons for these discrepancies are associated with the system used to classify the results by quality ranges and will therefore depend on the PSY limit established, which, in this study, was set at $10,000 \mathrm{CFU} / \mathrm{mL}$.

The average value obtained in the statistical analysis can be applied in a global analysis by dairy industries in order to evaluate the impact of different measures to reduce microbial counts.

3.4. Energy Saving in Industry. As a consequence of the reduction of microbial counts in milk after daily collection, a decrease of $4^{\circ} \mathrm{C}$ could be applied in the heat treatment of milk at the industry maintaining organoleptic characteristics 
TABle 5: Total energy savings expressed as key performance index (KPI) during 2015 (typical heat treatment) and 2016 (heat treatment reducing $4^{\circ} \mathrm{C}$ ) and percentage savings per unit of energy.

\begin{tabular}{lcccc}
\hline Month & KPI (typical HT) & KPI (modified HT) & Energy saving $(\%)$ & KPI saving $(\%)$ \\
\hline April & 0.18 & 0.13 & 35 & 44 \\
May & 0.19 & 0.13 & 52 & 46 \\
June & 0.19 & 0.12 & 39 & 52 \\
July & 0.15 & 0.11 & 5 & 38 \\
August & 0.13 & 0.12 & 8 & 5 \\
September & 0.13 & 0.12 & 15 & 7 \\
October & 0.14 & 0.13 & 16 & 2 \\
November & 0.14 & 0.14 & & 13 \\
December & 0.16 & 0.14 & & \\
\hline
\end{tabular}

HT: heat treatment.

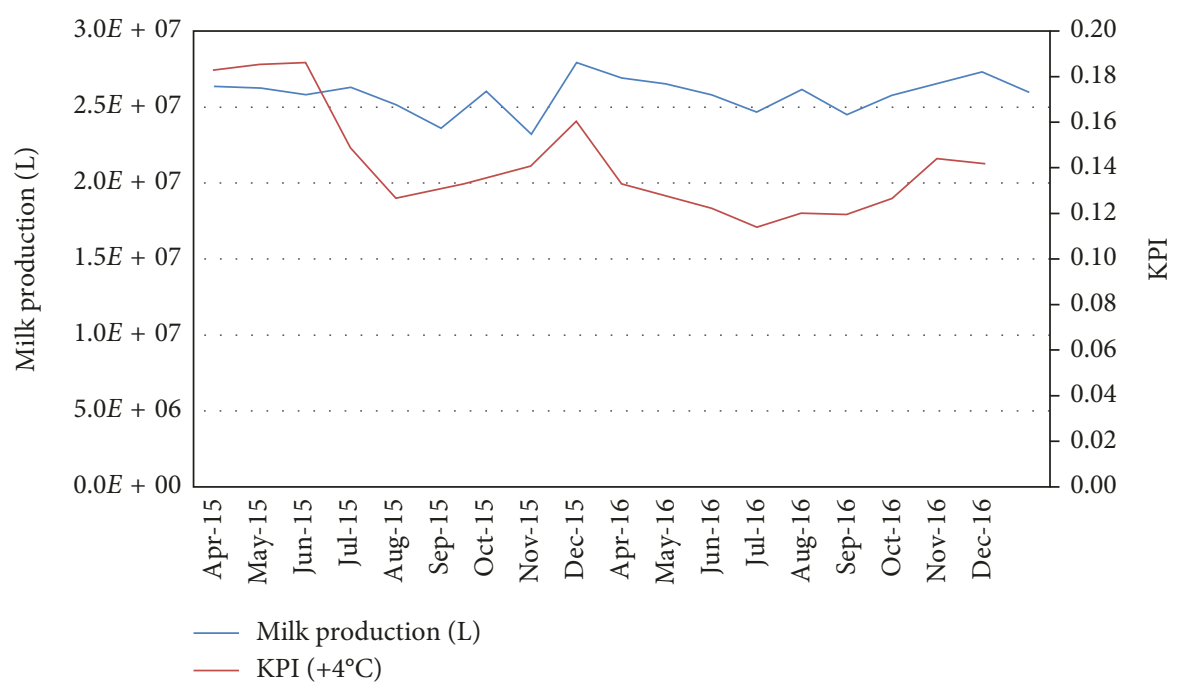

FIGURE 2: Graphical representation of milk production (liters) and the key performance index (KPI) during the 8-month study period, comparing $2015\left(+4^{\circ} \mathrm{C}\right)$ and $2016\left(-4^{\circ} \mathrm{C}\right)$.

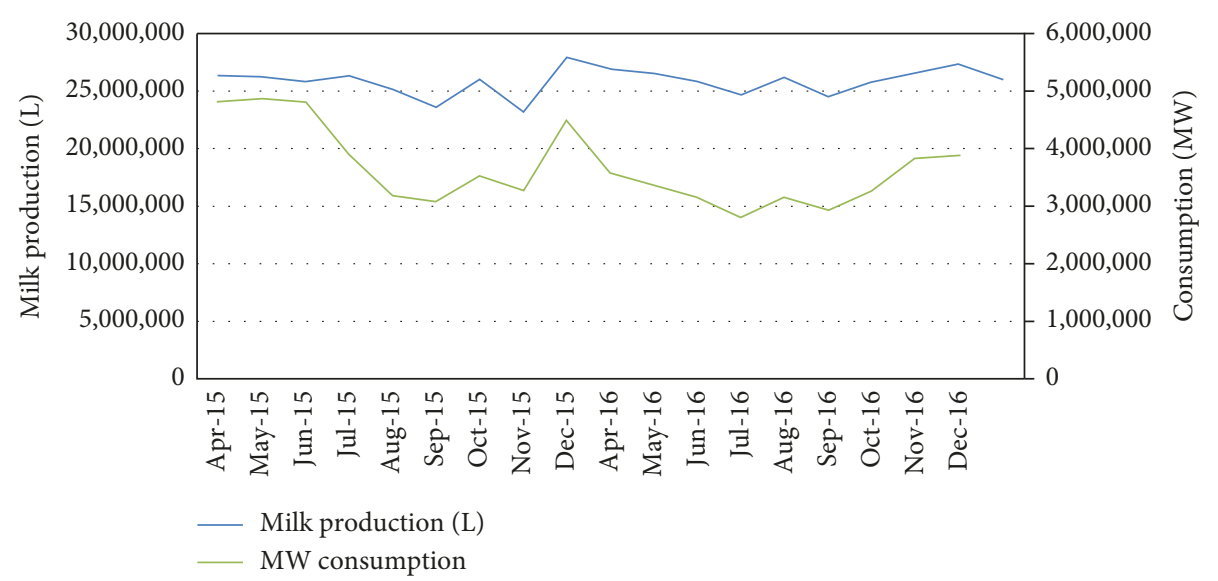

FIGURE 3: Graphical representation of megawatt consumption (MW) during the 8-month study period, comparing 2015 ( $+4^{\circ} \mathrm{C}$ ) and 2016 $\left(-4^{\circ} \mathrm{C}\right)$.

and food safety. A comparison of key performance index (KPI) and percentage savings per unit of energy per month for typical and modified heat treatments (reducing $4^{\circ} \mathrm{C}$ ) is presented in Table 5. An average saving of 22\% (per unit of energy) was achieved associated with the modified heat treatment.

Over the analyzed period, it can be observed that the higher milk production occurred in December in both periods 
(the first one since April 2015 to December 2015 and the second one since April 2016 to December 2016). This fact implied a higher cost of production in order to treat the total milk produced (liters) compared with months with less production (September) (Figure 2). Another important factor is the reduction of KPI associated with the summer months (July, August, and September), with an associated reduced megawatt consumption (MW) (Figures 2 and 3).

The increase of heating temperature and/or time is associated with denaturation of $\alpha$-lactalbumin and $\beta$-lactoglobulin, which bind to the surface of casein micelles. Heat treatment induces changes of the protein structure at the molecular level. The reduction of temperature and/or time of the treatment may be associated with beneficial compensation for the negative impact of heat treatment on the organoleptic properties of milk protein-based emulsions [8].

These results suggest that the daily collection of milk not only reduced the MAB counts of milk but also allowed to reduce up to $4^{\circ} \mathrm{C}$ of the temperature of the heat treatment, ensuring the same final milk safety (checked by the quality control point of the industry at this stage) and energy costsaving associated with the steam produced by the lower heat temperature applied.

\section{Conclusions}

Daily milk collection was an effective measure to improve the hygienic-sanitary quality of raw milk, significantly reducing MAB counts by $32 \%$ in relation to $48 \mathrm{~h}$ collection. This improvement in microbiological quality has allowed to adjust the temperature of the subsequent heat treatment in milk without compromising its hygiene and quality.

On the other hand, milking dayshift played an important role in maintaining the microbiological quality, with lower counts being recorded when milking was performed in the morning. Further research is needed to determine the main reasons of this difference. The use of quality ranges used in this study for MAB and PSY counts based on EU regulations and scientific references may help the dairy industries to classify and analyze different measures adopted to improve milk quality and safety.

Finally, this study showed a practical application of the implementation of daily milk collection in the energetic savings resulting from a milder heat treatment helping to better preserve the organoleptic quality and safety of milk. Reduction of temperature yielded at the same time a lower steam generation, thus being more respectful to the environment.

\section{Conflicts of Interest}

The authors declare that they have no conflicts of interest.

\section{Acknowledgments}

The authors thank the Ministry of Education, Culture and Sport/MINECO and Banco Santander, Global Universities Division, within the framework of the International Campus of Excellence Program (ceiA3), for funding the postgraduate scholarships in companies.

\section{References}

[1] D. Samardžija, Š. Zamberlin, and T. Pogačić, "Psychrotrophic bacteria and milk and dairy products quality," Mljekarsivo, vol. 62, no. 2, pp. 77-95, 2012.

[2] B. Ozer and G. Akdemir-Evrendilek, Dairy Microbiology and Biochemistry: Recent Developments, ISBN: 978-81482235029, CRC Press, Boca Raton, FL, USA, 2014.

[3] M. L. Signorini, G. J. Sequeira, J. C. Bonazza et al., "Use of indicator microorganisms for the hygienic-sanitary conditions evaluation in the milk primary production," Revista Científica Fcv-Luz, vol. 18, no. 2, pp. 207-217, 2008.

[4] R. Toušová, L. Stádník, and J. Ducháček, "Effects of season and time of milking on spontaneous and induced lipolysis in bovine milk fat," Czech Journal of Food Science, vol. 31, no. 1, pp. 20-26, 2013.

[5] R. Cempírková, "Psychrotrophic vs. total bacterial counts in bulk milk samples," Veterinarni Medicina, vol. 47, no. 8, pp. 227-233, 2002.

[6] C. Baur, M. Krewinkel, B. Kranz et al., "Quantification of the proteolytic and lipolytic activity of microorganisms isolated from raw milk," International Dairy Journal, vol. 49, pp. 23-29, 2015.

[7] C.F. Novoa and L.P. Restrepo, "Influence of psychrotrophic bacteria in proteolytic activity of milk," Revista de la Facultad de Medicina Veterinaria y de Zootecnia (Bogotá), vol. 54, no. 1, ISSN: 0120-2952, 2007.

[8] V. Raikos, "Effect of heat treatment on milk protein functionality at emulsion interfaces: a review," Food Hydrocolloids, vol. 24, no. 4, pp. 259-265, 2010.

[9] Y. Barcina, M. A. Zorraquino, J. Pedauye, G. Ros, and F. Rincón, "Azidiol como conservante de muestras de leche," Anales de Veterinaria, vol. 3, pp. 65-69, 1987.

[10] M. C. Hayes and K. Boor, "Raw milk and fluid milk products," in Applied Dairy Microbiology, E. H. Marth and J. Steele, Eds., pp. 59-76, New York, USA, 2nd edition, 2001.

[11] A. L. López and D. Barriga, La leche. Composición y características. Tecnología, Postcosecha e Industria Agroalimentaria, Consejería de Agricultura, Pesca y Desarrollo Rural, Instituto de Investigación y Formación Agraria y Pesquera, 2016.

[12] A. Callejo and V. Díaz-Barcos, "Calidad de la leche. Lipolisis," Frisona Española, vol. 166, pp. 98-102, ISSN 0211-3767, 2008.

[13] D. M. Barbano, Y. Ma, and M. V. Santos, "Influence of raw milk quality on fluid milk shelf life," Journal of Dairy Science, vol. 89, no. 1, pp. E15-E19, 2006.

[14] E. Capodifoglio, A. M. Centola-Vidal, J. A. Santos Lima et al., "Lipolytic and proteolytic activity of Pseudomonas spp. isolated during milking and storage of refrigerated raw milk," Journal of Dairy Science, vol. 99, pp. 5214-5223, 2016.

[15] L. Quigley, O. Sullivan, C. Stanton et al., "The complex microbiota on raw milk," FEMS Microbiology Reviews, vol. 37, no. 5, pp. 664-698, 2013.

[16] S. C. Murphy, "Raw milk bacteria tests: standard plate count, preliminary incubation count, lab pasteurized count and coliform count-what do they mean for your farm?," in Proceedings of the National Mastitis Council Regional Meeting, pp. 34-42, Syracuse NY, USA, 1997.

[17] Ministerio de Medio Ambiente y Medio Rural y Marino, Guía para la Producción Responsable: Manual de Producción de Leche Cruda de Vaca, Spain. 


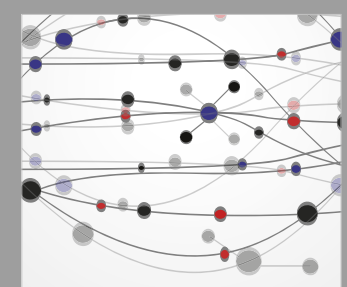

The Scientific World Journal
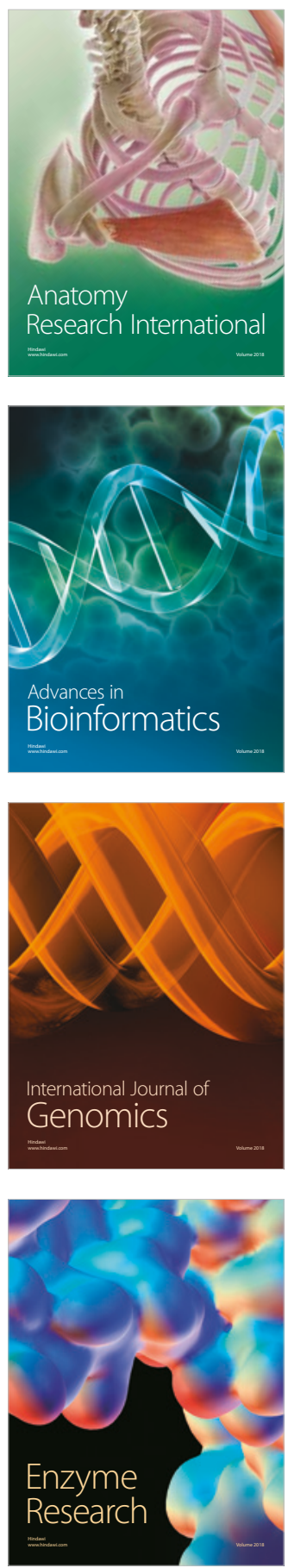
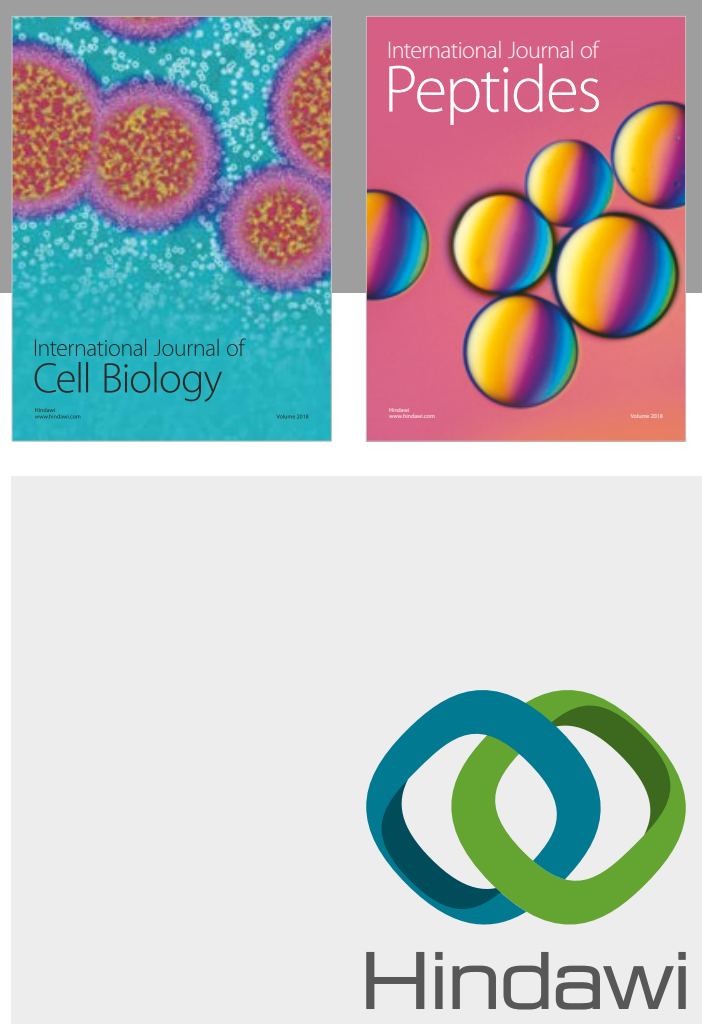

Submit your manuscripts at

www.hindawi.com
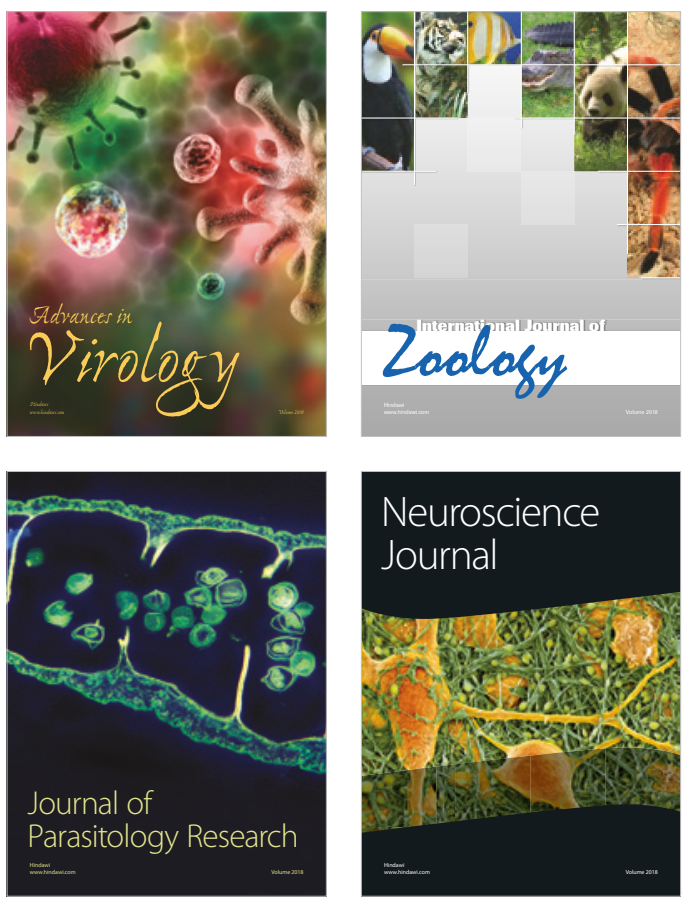
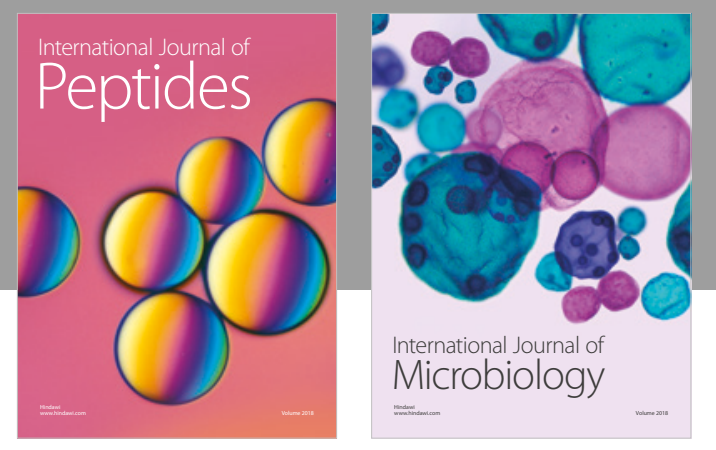

nternational Journal of Microbiology
Journal of
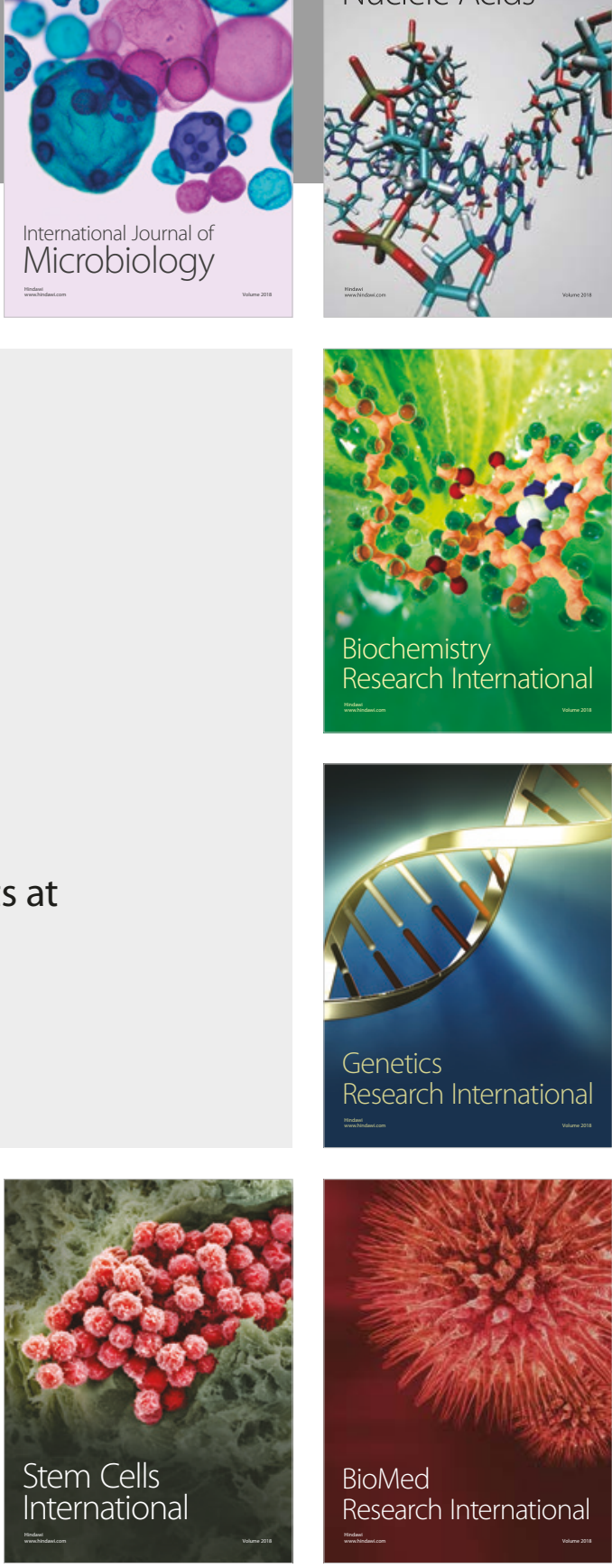
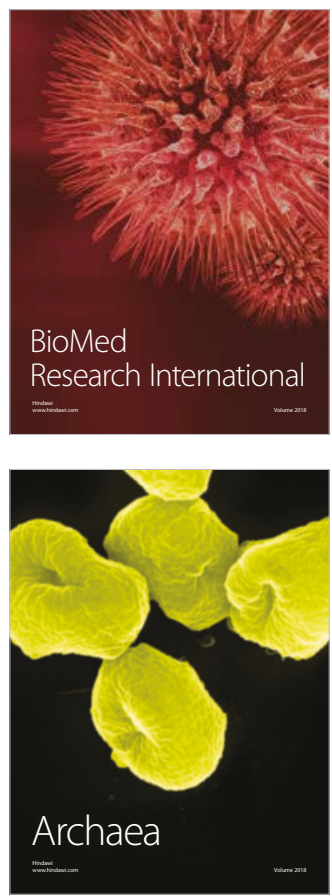